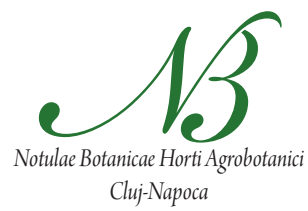

\title{
Micropropagation of the Endangered and Decorative Specie Dianthus serotinus Waldst. et Kit.
}

\author{
Marija MARKOVIĆ*, Mihailo GRBIĆ, Matilda DJUKIĆ \\ Belgrade University, Faculty of Forestry, Ulica kneza Višeslava, 1, 11000 Belgrad, Serbia; \\ marija.markovic@sfb.bg.ac.rs (*correspondingauthor);mihailo.grbic@sfb.bg.ac.rs; matilda.djukic@sfb.bg.ac.rs
}

\begin{abstract}
During past decades, great attention has been paid to propagation of endangered plant taxa in order to preserve biodiversity. The aim of this study was to optimize a protocol for in vitro propagation of the critically endangered and decorative species Dianthus serotinus Waldst. et Kit. The effects of different concentration of MS salt (Murashige and Skoog) of the culture, medium pH and different carbohydrates (sucrose, glucose, and fructose) on shoot multiplication were examined. The best results were obtained on half-strength MS (Murashige and Skoog) medium, whose $\mathrm{pH}$ was 5.8, with sucrose supplied at a concentration of 3\%, when shoots with 1-2 nodes or shoot tips (with terminal buds only) were used as explants. The shoots were rooted (76.7\%) on half-strength MS medium containing 0.5 $\mathrm{mg} \cdot \mathrm{L}^{-1}$ NAA (1-naphthaleneacetic acid). The obtained plantlets were successfully acclimatized (89\%) in a 4:1 mixture of peat and sand and they flowered the following year. Presented protocol enables successful in vitro propagation of $D$. serotinus.
\end{abstract}

Keywords: acclimatization, fructose, glucose, in vitro culture, $\mathrm{pH}$ value, sucrose

\section{Introduction}

Dianthus serotinus Waldst. et Kit. (Caryophyllaceae) is an endemic Pannonian species included in category $\mathrm{V}$ (vulnerable taxa) of the IUCN Red List of endangered species. It is under legal protection and has the status of extremely endangered species in Serbia (Law on Environmental Protection, Rulebook on protected species, 2010). This species is found in small numbers only locally in the area of Subotica - Horgoš Sands, where it is threatened by the expansion of agricultural land and afforestation (Boža, 1999). D. serotinus is a decorative plant with bluishgreen leaves and white flowers, which have a mild scent and a threadlike-rimmed corolla. This endangered species blooms all summer long and grows on poor sandy soils. It is drought tolerant, which makes it suitable for use as an ornamental in dry-stone constructions, rock and cottage gardens (Gajić, 1986; Boža, 1999).

To enable its ex situ and in situ conservation, we decided to propagate $D$. serotinus using the micropropagation method, which is a convenient method for rapid and efficient propagation of endangered species (Pence, 1999). Marković et al. (2007) established a sterile D. serotinus culture and investigated the effect of different concentrations of phytohormones on the multiplication and rooting of shoots of this species. However, their work examined the effect of phytohormones in a small number of treatments, and the acclimatization of the plantlets obtained was not performed. Considering that $D$. serotinus grows on humus-poor sand with $\mathrm{pH}$ ranging from 7.0 to 8.1 in natural habitat (Boža, 1999) and that $\mathrm{pH}$ medium in pre- vious research was 5.8 (Marković et al., 2007) we needed to improve protocol for regeneration and multiplication of this plant species.

Beside different concentrations of phytohormones that affect the development of in vitro cultures, important components are carbohydrates as sources of energy and carbon and osmotic agents that regulate the uptake of other culture constituents. In addition, the concentration and type of a carbohydrate in a medium can affect organogenesis and the development of an in vitro culture (Mohamed and Alsadon, 2010; Nowak et al., 2004; Todorović et al., 2006; Thorpe et al., 2008). Although sucrose is the most widely used carbohydrate and the cheapest one (Thorpe et al., 2008), other carbohydrates, mainly glucose and fructose, had a better effect on the development of in vitro cultures of some species, i.e. seven species of the genus $\mathrm{Al}$ nus (Tremblay and Lalonde, 1984; Barghchi, 1988), Bougainvillea 'San Diego Red' (Steffen et al., 1988), Castanea sativa Mill., C. crenata Siebold et Zucc. (Chauvin and Salesses, 1988), Nepeta rtanjensis Diklić et Milojević (Mišić et al., 2005b), Corylus avelana L. (Yu and Reed, 1993), Fagus spp. (Cuenca and Vieitez, 2000). Therefore, variations of carbohydrate components in a growth medium are inevitably taken into consideration in the optimization of protocols for in vitro propagation of certain plant species.

A large number of studies have been published on the micropropagation of endangered and/or endemic Dianthus species in the Balkans. They include the studies of endemic endangered species of the Czech Republic $D$. arenarius L. ssp. bohemicus (Novák) O. Schwarz (Kovác, 1995 ) and D. superbus L. ssp. superbus Domin (Mikulík, 
1999), the endemic species of the Balkan Peninsula D. petraeus Waldst. \& Kit. ssp.noeanus (Boiss.) Tutin (Radojević et al., 1997), D. giganteus d'Urv. ssp. croaticus (Borbás) Tutin and D. ciliatus Guss. ssp. dalmaticus (Čelak.) Hayek (Radojević et al., 2006, Radojević et al., 2010), the endemic and endangered species of Romania D. spiculifolius Schur (Butiuc-Keul et al., 2001), D. petraeus Waldst. \& Kit. ssp. simonkaianus (Péterfi) Tutin (Miclăuş et al., 2003), D. callizonus Schott \& Kotschy (Holobiuc and Blindu, 2006), D. nardiformis Janka (Holobiuc et al., 2009, 2010a), D. pratensis M. Bieb. subsp. racovitzae (Prodan) Tutin (Cristea, 2010), D. henteri Heuff. ex Griseb. \& Schenk (Cristea et al., 2010), D. glacialis Haenke ssp. gelidus (Schott, Nym. et Kotschy) Tutin (Holobiuc et al., 2010b), D. giganteus d'Urv. subsp. banaticus (Heuff. ex Griseb. \& Schenk) Tutin (Pop and Pamfil, 2011), in Greece D. fruticosus L. (Papafotiou and Stragas, 2009) and many other studies. Also, to date, many studies regarding the optimization of the in vitro protocol of important decorative Dianthus taxa, including $D$. chinensis L., D. barbatus L. had been published (Jethwani and Kothari, 1993; Jethwani et al., 1994; Pareek et al., 2004). All mentioned studies investigated the optimal concentration of phytohormones added to MS culture media or less often half-strength MS media that differed depending on the species (Murashige and Skoog, 1962). The $\mathrm{pH}$ level was adjusted to 5.8 before autoclaving and $2 \%$ or even more often $3 \%$ sucrose was used as a source of carbohydrates. However, none of these papers investigated the effect of $\mathrm{pH}$ or different concentrations of different carbohydrates on the in vitro development of Dianthus spp. cultures. Taking all this into account, the aim of our research was to perform a detailed and complete study of the improvement of a protocol for the micropropagation and acclimatization of D. serotinus. This investigation included examining of the impact of culture medium $\mathrm{pH}$, various carbohydrates and the development of in vitro cultures on the media with reduced concentrations of MS salts.

\section{Materials and methods}

The in vitro culture was established from seeds collected at the locality of Subotica - Horgoš Sands, in the vicinity of Palić. The seeds were surface disinfected by immersion in $4 \% \mathrm{NaOCl}$ (sodium hypochlorite) supplemented with 2-3 drops of the Tween 20 for 20 minutes before three rinses in sterile, distilled water according to the procedure described by Marković et al. (2007). Three weeks later, nodal and shoot tip cuttings (with terminal buds only) were cut from the seedlings. These cuttings were placed on a multiplication culture medium containing Murashige and Skoog (MS) salts and vitamins ( $\mathrm{Mu}-$ rashige and Skoog, 1962), 3\% sucrose, $0.8 \%$ agar and 0.5 $\mathrm{mg} \cdot \mathrm{L}^{-1} \mathrm{BAP}$ (6-benzylaminopurine) and $0.5 \mathrm{mg} \cdot \mathrm{L}^{-1} \mathrm{NAA}$ (1-naphtalenacetic acid), as recommended by Marković et al. (2007) to obtain the material of sufficient quantity to set up the next experiment. Before the experiment setup, the shoots were cultured for 2 weeks on MS basal culture medium without phytohormones.

In all experiments three different types of explants (shoot tip cuttings with terminal buds only, single node cuttings with axillary buds only and shoots with 1-2 nodes) were placed on either solid MS or half-strength MS culture medium containing $0.8 \%$ agar, supplemented with $0.5 \mathrm{mg} \cdot \mathrm{L}^{-1} \mathrm{BAP}$ and $0.5 \mathrm{mg} \cdot \mathrm{L}^{-1} \mathrm{NAA}$. The effect of culture medium $\mathrm{pH}$ supplemented with $3 \%$ sucrose on shoot induction and multiplication of D. serotinus was investigated. In this experiment the $\mathrm{pH}$ was adjusted before autoclaving the culture medium $\left(20 \mathrm{~min}\right.$ at $\left.120^{\circ} \mathrm{C}\right)$ to the four graded values $(5.8,6.8,7.8$ and 8.8$)$. In the second experiment we investigated the effect of graded concentration $(1 \%, 3 \%, 5 \%$ and $7 \%)$ of three different carbohydrate source (sucrose, glucose and fructose) on shoot induction and multiplication of D. serotinus. Considering that high concentration of sugar decreased culture medium $\mathrm{pH}$ (Thorpe et al., 2008), in this experiment the $\mathrm{pH}$ value of all tested media was set to 6.3 before autoclaving. During the multiplication stage, the culture medium was poured into glass vessels of $5 \times 5 \times 13 \mathrm{~cm}$ dimensions. The vessels contained $25 \mathrm{~mL}$ of the culture medium and 5 explants of the same type were placed in each of them. The experiments were repeated 3 times with 20 explants per treatment. After 25 days of cultivation, the following parameters were determined: the number of shoots per explant, the number of nodes and shoot length.

During the rooting stage, the shoots (with 1-3 nodes) were placed on basal medium (MS or half-strength MS) supplemented with NAA $\left(0.0-0.5 \mathrm{mg} \cdot \mathrm{L}^{-1}\right)$. The shoots were placed in glass containers of $8 \times 8 \times 15 \mathrm{~cm}$ dimensions, with $100 \mathrm{~mL}$ of medium and 15 shoots were placed in each of them. The experiments were repeated 3 times with 30 explants per treatment. After 15 days, the percentage of rooted plants, the number of roots and the length of the longest root per explant were determined.

During the acclimatization stage, the rooted plantlets were planted in three different mixtures of culture substrates, including (1:1) and (4:1) mixtures of peat and sand, and a (2:2:2:1) mixture of peat, sand, garden soil and burned farmyard manure. Before use, the soil was treated with a $1.5 \%$ solution of Previcur-N fungicide. Each treatment consisted of three replications with 30 plantlets. The planted plants were covered with perforated plastic wrap to maintain high relative humidity during the first 15 days of acclimatization. Ventilation was applied once daily for 5-10 minutes, after which the plastic wrap was removed. The plants were grown for 10 more days, and after that, their survival rate was recorded.

Plant cultures for all in vitro experiments were grown in a growth room under a 16/8-h (day/night) photoperiod and a photon flux rate of $50 \mu \mathrm{mol} \cdot \mathrm{m}^{-2} \cdot \mathrm{s}^{-1}$ at $25 \pm 2^{\circ} \mathrm{C}$ in the light of fluorescent white pipes. 
372

Statistical data processing was performed using an appropriate application for statistical analyses (Statgraphics, version 5.0). The significance of differences between the means was determined by the analysis of variance (ANOVA, $\mathrm{p}<0.05)$ and the least significant difference (LSD) test.

\section{Results and discussion}

\section{Effect of the medium $p H$ on shoot development}

The in vitro culture was successfully established according to the procedure described by Marković et al. (2007). The concentration of MS salts (MS or half-strength MS) and culture medium $\mathrm{pH}$, affected the frequency of shoot regeneration on the media of different $\mathrm{pH}$ levels, whereas this frequency was unaffected by explant type (Tab. 1). Contrary to expectations, regardless of the concentration of mineral salts, the shoot regeneration on explants was high on nutrition media with low $\mathrm{pH}$. The difference between parameters obtained on the media of 5.8 and 6.8 $\mathrm{pH}$ levels was generally not statistically significant. On the media with a $\mathrm{pH}$ level of 7.8 , the frequency of regeneration significantly decreased, whereas almost none of the explants developed on alkaline media with a $\mathrm{pH}$ level of 8.8 so the growth parameters couldn't be measured. In addition, the frequency of regeneration was higher on halfstrength MS media (from 60.5 to $98.9 \%$ ) compared to MS media (from 35.3 to $73.5 \%$ ). However, the shoots on MS media were better developed, containing a higher average number of shoots per explant (Tab. 2). A high frequency of regeneration on half-strength MS media was achieved in the species D. nardiformis (Holobiuc et al., 2010a). However, it is not clear whether the lower concentrations of salts were more favourable for this species because the MS and half-strength MS media were supplemented with different concentrations and types of hormones.

Tab. 1. Frequency of shoot regeneration on different explants cultured on graded $\mathrm{pH}$ media after 25 days in vitro

\begin{tabular}{ccccc}
\hline $\begin{array}{c}\mathrm{pH} \\
\text { value }\end{array}$ & Medium & $\begin{array}{c}\text { Single node } \\
\text { cuttings (\%) }\end{array}$ & $\begin{array}{c}\text { Shoot } \\
\text { tips (\%) }\end{array}$ & Shoots (\%) \\
\hline 5.8 & $\mathrm{MS}_{0}$ & $58.9 \pm 9.1^{\mathrm{abc}}$ & $65.5 \pm 8.8^{\mathrm{c}}$ & $73.5 \pm 9.1^{\mathrm{b}}$ \\
\hline 6.8 & $\mathrm{MS}_{0}$ & $50.2 \pm 8.0^{\mathrm{bc}}$ & $68.3 \pm 9.1^{\mathrm{c}}$ & $72.1 \pm 8.2^{\mathrm{b}}$ \\
\hline 7.8 & $\mathrm{MS}_{0}$ & $35.3 \pm 7.6^{\mathrm{c}}$ & $30.2 \pm 7.2^{\mathrm{d}}$ & $38.2^{\mathrm{c}} \pm 8.6^{\mathrm{c}}$ \\
\hline 8.8 & $\mathrm{MS}_{0}$ & $0.0 \pm 0.0^{\mathrm{d}}$ & $3.3 \pm 1.7^{\mathrm{c}}$ & $1.7 \pm 1.7^{\mathrm{d}}$ \\
\hline 5.8 & $1 / 2 \mathrm{MS}_{0}$ & $70.3 \pm 8.3^{\mathrm{a}}$ & $98.9 \pm 1.1^{\mathrm{a}}$ & $97.3 \pm 2.7^{\mathrm{a}}$ \\
\hline 6.8 & $1 / 2 \mathrm{MS}_{0}$ & $65.2 \pm 7.5^{\mathrm{ab}}$ & $90.8 \pm 8.3^{\mathrm{ab}}$ & $92.5 \pm 6.7^{\mathrm{a}}$ \\
7.8 & $1 / 2 \mathrm{MS}_{0}$ & $60.5 \pm 7.5^{\mathrm{ab}}$ & $81.5 \pm 6.9^{\mathrm{b}}$ & $73.8 \pm 7.1^{\mathrm{b}}$ \\
\hline
\end{tabular}

$\mathrm{MS}_{0}$ - basal medium containing MS mineral salts; $1 / 2 \mathrm{MS}_{0}$ - basal medium containing half strength MS mineral salts;

Note: Values followed by different letters are significantly different at the $\mathrm{P}<0.05$ level according to the least significant difference test

In determining the average number of nodes per explant, only the nodes that could be used for the next sub- culture, i.e. those whose axillary buds did not develop into new shoots were taken into account as potential nodal cuttings for the next subculture, and their number varied, although it could be observed that their number was generally high on media with low $\mathrm{pH}$ (Tab. 2).

Tab. 2. The average number of shoots and shoot nodes regenerated on different explants cultured on graded $\mathrm{pH}$ media after 25 days in vitro

\begin{tabular}{|c|c|c|c|c|c|c|}
\hline \multirow{2}{*}{$\begin{array}{c}\mathrm{pH} \\
\text { value }\end{array}$} & \multicolumn{2}{|c|}{ Single node cuttings } & \multicolumn{2}{|c|}{ Shoot tips } & \multicolumn{2}{|c|}{ Shoots } \\
\hline & $\mathrm{MS}_{0}$ & $1 / 2 \mathrm{MS}_{0}$ & $\mathrm{MS}_{0}$ & $1 / 2 \mathrm{MS}_{0}$ & $\mathrm{MS}_{0}$ & $1 / 2 \mathrm{MS}_{0}$ \\
\hline \multicolumn{7}{|c|}{ No. of shoots per explant } \\
\hline 5.8 & $10.1 \pm 1.1^{\mathrm{a}}$ & $4.5 \pm 0.7^{a}$ & $8.8 \pm 0.7^{a b}$ & $7.8 \pm 0.6^{b}$ & $\begin{array}{c}10.7 \pm \\
0.6^{\mathrm{ab}}\end{array}$ & $\begin{array}{l}7.5 \pm \\
0.3^{\mathrm{ab}}\end{array}$ \\
\hline 6.8 & $5.8 \pm 0.8^{b}$ & $5.3 \pm 0.7^{\mathrm{ab}}$ & $\begin{array}{c}11.5 \pm \\
0.6^{b}\end{array}$ & $7.2 \pm 0.5^{b}$ & $\begin{array}{c}11.5 \pm \\
0.3^{a}\end{array}$ & $\begin{array}{l}5.8 \pm \\
0.4^{b}\end{array}$ \\
\hline 7.8 & $6.0 \pm 1.2^{b}$ & $5.8 \pm 1.0^{b}$ & $6.9 \pm 0.6^{a}$ & $4.6 \pm 0.3^{a}$ & $9.3 \pm 0.3^{b}$ & $\begin{array}{l}8.2^{ \pm} \\
0.3^{a}\end{array}$ \\
\hline \multicolumn{7}{|c|}{ No. of nodes per explant } \\
\hline 5.8 & $11.1 \pm 0.8^{a}$ & $7.1 \pm 0.7^{\mathrm{ab}}$ & $\begin{array}{c}12.3 \pm \\
1.2^{\mathrm{ab}}\end{array}$ & $\begin{array}{c}15.1 \pm \\
1.3^{\mathrm{a}}\end{array}$ & $\begin{array}{c}11.2 \pm \\
1.2^{\mathrm{ab}}\end{array}$ & $\begin{array}{c}13.5 \pm \\
1.0^{\mathrm{a}}\end{array}$ \\
\hline 6.8 & $4.6 \pm 0.4^{b}$ & $7.9 \pm 0.7^{\mathrm{ab}}$ & $14.9 \pm 1.0^{\mathrm{a}}$ & $\begin{array}{c}11.9 \pm \\
0.9^{\mathrm{ab}}\end{array}$ & $\begin{array}{c}14.5 \pm \\
1.2^{\mathrm{a}}\end{array}$ & $\begin{array}{c}10.5 \pm \\
0.8^{\mathrm{ab}}\end{array}$ \\
\hline 7.8 & $6.1 \pm 1.1^{\mathrm{ab}}$ & $8.9 \pm 0.3^{a}$ & $7.1 \pm 0.9^{b}$ & $9.2 \pm 1.1^{b}$ & $8.1 \pm 0.6^{b}$ & $\begin{array}{c}9.3 \pm \\
0.7^{\mathrm{b}}\end{array}$ \\
\hline
\end{tabular}

$\mathrm{MS}_{0}$ - basal medium containing MS mineral salts; $1 / 2 \mathrm{MS}_{0}$ - basal medium containing half strength MS mineral salts;

Note: Values followed by different letters are significantly different at the $\mathrm{P}<0.05$ level according to the least significant difference test.

Because of the high level of variability in shoot length, the shoots were placed in different length categories (less than $10 \mathrm{~mm}, 10-20 \mathrm{~mm}$ and more than $20 \mathrm{~mm}$ ) and the number of shoots belonging to a certain length category was expressed as a percentage of the total number of shoots. Generally, the shoots were longer on MS basal media. In some cases (nodal explants on media with 5.8 and $6.8 \mathrm{pH}$ levels), over $40 \%$ of the shoots were longer than $20 \mathrm{~mm}$, while in the case of half-strength MS media, the percentage of shoots longer than $20 \mathrm{~mm}$ did not exceed $20 \%$ on all media, regardless of the culture medium $\mathrm{pH}$ and explant type (Fig. 1). The importance of medium $\mathrm{pH}$ for in vitro development of plants is already known (Leifert et al., 1992; Harbage and Stimart, 1996). Nevertheless, in Maranta leuconeura cv. Kerchoviana different $\mathrm{pH}$ levels of a culture medium had no significant effect on the development of cultures, and there were no statistically significant differences in either rooting percentage or the average number of leaves per shoot and shoot length. Only the differences in the number of shoots per explant were observed (Ebrahim and Ibrahim, 2000). However, Bhatia and Ashwath (2005) showed that a change in medium $\mathrm{pH}$ did not significantly affect the number of shoots formed per explant of Lycopersicum esculentum cv. Red Coat, although it had an effect on their length. In addition, Ostrolucka et al. (2004) revealed that a lower pH level of 5.0 was 
more favourable than $\mathrm{pH} 5.5$ for acidophilic Vaccinium corymbosum 'Duke'. Additionally, a research on the effect of $\mathrm{pH}$ on axillary shoot proliferation in Vaccinium vitisidaea L. showed that the optimum $\mathrm{pH}$ ranged from 4.0 to 5.5, depending on the cultivar (Ostrolucka et al., 2010). On the other hand, the research of Mišić et al. (2005a) showed that the high $\mathrm{pH}$ levels of 7.0 - 7.2 were the most suitable for the proliferation of lateral buds and the rooting of shoots of the calciphilic species Nepeta rtanjensis. However, contrary to expectations, our research showed that $\mathrm{pH}$ levels ranging from $5.8-6.8$ were the most suitable for the species $D$. serotinus, while at higher $\mathrm{pH}$ levels the development of shoots in in vitro culture significantly decreased. A possible explanation for this phenomenon may lie in the specific conditions of in vitro culture and the fact that the adoption of mineral salts from culture medium, and thus the growth of plants, is influenced by not only the concentration of salts, but also $\mathrm{pH}$, temperature, and the biochemical or physiological status of the plant tissues (George and de Klerk, 2008). Also, specific conditions of in vitro culture have a different influence on growth and development of the species belonging to distinct plant families with different metabolism and the response of $D$. serotinus perhaps was depending on interaction of mentioned factors, in different way than other studied species. Therefore, we can assume that a higher $\mathrm{pH}$ value would be better in case of a different composition of mineral components of the culture medium. This was confirmed by the data listed in Tab. 1 showing that better results were obtained on half-strength $\mathrm{MS}$ media with $\mathrm{pH}$ 7.8 than on MS media with $\mathrm{pH}$ values of 5.8 and 6.8 for the same type of explant.

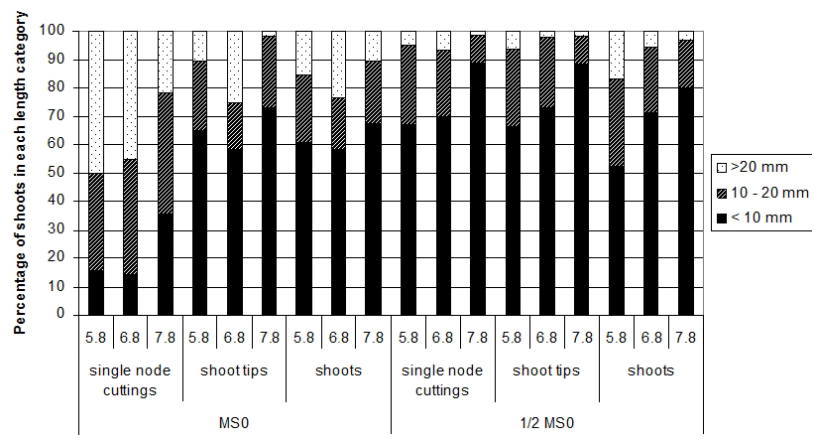

Fig. 1. The effect of graded medium $\mathrm{pH}$ on length of $D$. serotinus shoots regenerated on different explants on full-strength MS basal medium ( $\mathrm{MS}_{0}$ ) and half-strength MS basal medium $\left(1 / 2 \mathrm{MS}_{0}\right)$

\section{The effect of carbon source on shoot regeneration}

Generally, sucrose had the most favourable effect on the regeneration of explants. Glucose had the second most favourable effect, while the lowest frequency of regeneration was recorded on media containing fructose (Tab. 3). When explants were cultured on half-strength basal media, a low frequency of regeneration occurred only on nutrition media with high concentrations of glucose or fructose $(7 \%)$. However, the frequency of regeneration was significantly lower on MS basal media. It was also affected by explant type, showing a higher regeneration rate of shoots than in the case of shoot tips and single node cuttings. Similarly, the highest average number of shoots was formed on MS basal medium with sucrose (from 6.2-nodal cuttings to 9.5-shoot tip cuttings). The average number of shoots was lower on media containing glucose and fructose, and generally, the best results were obtained if the concentration of these sugars was 3\% (Fig. 2). Similar results were obtained by observing the average number of nodes that can be used for the next subculture, the MS basal media with sucrose supplied at a concentration of $3 \%$, were the best, while the media with glucose and fructose, and half-strength MS medium with sucrose yielded poorer results (Fig. 3). As far as shoot length is concerned, regardless of the type and concentration of sugar, significantly longer shoots were formed on MS basal media. The percentage of shoots longer than $20 \mathrm{~mm}$ was generally $50 \%$ or higher on media containing glucose and sucrose, whereas on half-strength MS basal media it usually did not exceed $10 \%$, reaching $32 \%$ only on the medium with $1 \%$ glucose (Fig. 4). In the examination of the effect of concentration and type of carbohydrate on the in vitro growth and organogenesis of the species Rindera umbellata, the highest frequency of adventitious buds formation on the stem explants was reached on medium with $0.06 \mathrm{M}(\approx$ $2 \%)$ sucrose, but the highest values of fresh and dry weight were obtained on medium with $0.1 \mathrm{M}(\approx 3.4 \%)$ sucrose (Perić et al., 2012). In contrast, glucose provided optimum growth and morphogenesis of the shoots of Nepeta rtanjensis (Mišić et al., 2005b). During the shoot multiplication of the species Fagus sylvatica and F. orientalis on media containing (3-4\%) glucose, the number of shoots per explant was higher than on media containing sucrose or fructose. However, the effect of different sugars on shoot length varied depending on the clone of $F$. orientalis cultivated (Cuenca and Vieitez, 2000). Similarly, during the micropropagation of different cultivars and clones of $\mathrm{Vac}$ cinium vitis-idaea, optimum effects of carbohydrate type and concentration differed (Debnath, 2005). Considering that sucrose is the most commonly used carbohydrate (Thorpe et al., 2008), the results obtained in our research could be expected ones. Nevertheless, taking into account above-mentioned reports of better effect of other carbohydrates (e.g. glycose) on in vitro growth and development, and different response of different plants species and even the clones to variation of type and concentration of carbohydrates, we could assume that optimum results during in vitro culture of some other Dianthus species possibly would be achieved with carbohydrate other than sucrose. 
374

Tab. 3. Frequency of shoot regeneration on different explants cultured on media supplemented with different carbohydrate source and graded concentration after 25 days in vitro

\begin{tabular}{|c|c|c|c|c|c|c|c|}
\hline \multirow{2}{*}{ Type of sugar } & \multirow{2}{*}{ Concentration } & \multicolumn{2}{|c|}{ Single node cuttings (\%) } & \multicolumn{2}{|c|}{ Shoot tips (\%) } & \multicolumn{2}{|c|}{ Shoots (\%) } \\
\hline & & $\mathrm{MS}_{0}$ & $1 / 2 \mathrm{MS}_{0}$ & $\mathrm{MS}_{0}$ & $1 / 2 \mathrm{MS}_{0}$ & $\mathrm{MS}_{0}$ & $1 / 2 \mathrm{MS}_{0}$ \\
\hline sucrose & $1 \%$ & $85.0 \pm 11.2^{a}$ & $91.6 \pm 5.7^{\mathrm{a}}$ & $68.4 \pm 7.2^{b}$ & $96.7 \pm 2.1^{\text {a }}$ & $88.3 \pm 6.4^{a}$ & $95.0 \pm 1.8^{\mathrm{a}}$ \\
\hline sucrose & $3 \%$ & $73.3 \pm 6.5^{\mathrm{abc}}$ & $90.0 \pm 5.6^{\mathrm{a}}$ & $90.0 \pm 5.6^{a}$ & $98.3 \pm 1.7^{a}$ & $90.0 \pm 4.1^{\mathrm{a}}$ & $96.7 \pm 2.0^{\mathrm{a}}$ \\
\hline sucrose & $5 \%$ & $70.0 \pm 6.8 \mathrm{abc}$ & $90.0 \pm 5.6^{\mathrm{a}}$ & $81.7 \pm 8.3^{\mathrm{ab}}$ & $96.7 \pm 1.1^{a}$ & $90.0 \pm 2.3^{\mathrm{a}}$ & $96.7 \pm 2.7^{a}$ \\
\hline sucrose & $7 \%$ & $83.3 \pm 5.8^{\mathrm{ab}}$ & $88.3 \pm 8.1^{\mathrm{ab}}$ & $73.3 \pm 8.3^{\mathrm{ab}}$ & $91.7 \pm 5.3^{\mathrm{a}}$ & $86.7 \pm 5.1^{\mathrm{a}}$ & $95.0 \pm 2.4^{\mathrm{a}}$ \\
\hline glucose & $1 \%$ & $21.7 \pm 4.3^{c}$ & $98.3 \pm 1.7^{\mathrm{a}}$ & $36.6 \pm 10.5^{b c}$ & $98.3 \pm 1.7^{\mathrm{a}}$ & $60.0 \pm 5.1^{\mathrm{ab}}$ & $98.3 \pm 1.7^{\mathrm{a}}$ \\
\hline glucose & $3 \%$ & $18.3 \pm 5.0^{c}$ & $98.3 \pm 1.7^{a}$ & $65.0 \pm 9.1^{b}$ & $96.7 \pm 2.4^{\mathrm{a}}$ & $85.0 \pm 4.8^{a b}$ & $98.3 \pm 0.8^{a}$ \\
\hline glucose & $5 \%$ & $16.7 \pm 5.2^{\mathrm{cd}}$ & $95.0 \pm 3.3^{a}$ & $51.6 \pm 8.9^{\mathrm{bc}}$ & $96.7 \pm 2.4^{\mathrm{a}}$ & $56.7 \pm 8.2^{b}$ & $98.3 \pm 0.8^{\mathrm{a}}$ \\
\hline glucose & $7 \%$ & $6.7 \pm 3.3^{\mathrm{de}}$ & $91.7 \pm 4.1^{\mathrm{a}}$ & $11.7 \pm 4.6^{\mathrm{cd}}$ & $80.0 \pm 5.6^{a}$ & $15.0 \pm 3.3^{b c}$ & $95.0 \pm 2.4^{\mathrm{a}}$ \\
\hline fructose & $1 \%$ & $11.7 \pm 3.7^{\mathrm{cd}}$ & $96.7 \pm 3.3^{a}$ & $35.0 \pm 5.2^{\mathrm{cd}}$ & $98.3 \pm 0.8^{a}$ & $18.3 \pm 2.6^{b c}$ & $96.7 \pm 1.8^{a}$ \\
\hline fructose & $3 \%$ & $48.3 \pm 7.1^{b c}$ & $96.7 \pm 3.3^{a}$ & $48.3 \pm 5.7^{c}$ & $95.0 \pm 2.3^{a}$ & $41.7 \pm 5.8^{b c}$ & $93.3 \pm 2.3^{a}$ \\
\hline fructose & $5 \%$ & $25.0 \pm 6.2^{c}$ & $80.0 \pm 8.8^{a b}$ & $20.0 \pm 5.1^{\mathrm{cd}}$ & $70.0 \pm 5.4^{b}$ & $28.3 \pm 5.1^{b c}$ & $80.0 \pm 7.1^{\mathrm{ab}}$ \\
\hline fructose & $7 \%$ & $3.3 \pm 1.7^{\mathrm{de}}$ & $65.0 \pm 7.4^{b}$ & $5.0 \pm 2.7^{\mathrm{d}}$ & $61.7 \pm 6.7^{b}$ & $23.4 \pm 4.5^{b c}$ & $76.7 \pm 7.3^{b}$ \\
\hline
\end{tabular}

$\mathrm{MS}_{0}$ - basal medium containing MS mineral salts; $1 / 2 \mathrm{MS}_{0}$ - basal medium containing half strength MS mineral salts;

Note: Values followed by different letters are significantly different at the $\mathrm{P}<0.05$ level according to the least significant difference test

A

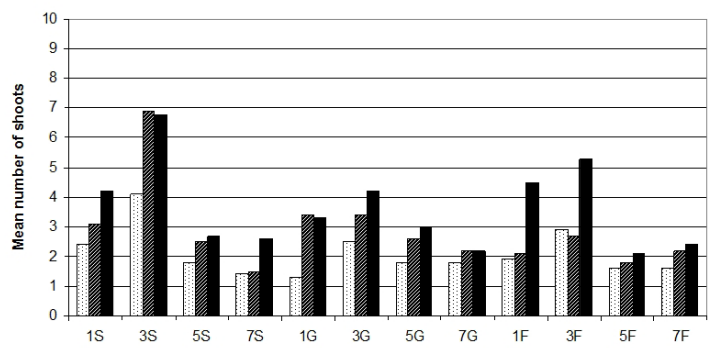

B

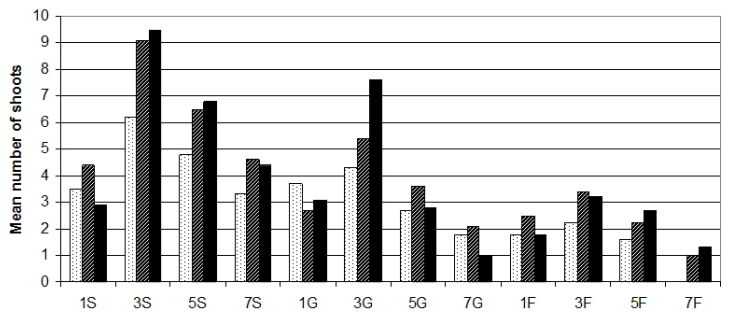

Gsingle node cuttings shoot tips $\mathbf{s h o o t s}$

Fig. 2. The effect of graded concentration of different carbohydrate source on number of regenerated $D$. serotinus shoots on full-strength MS basal medium (B) and half-strength MS basal medium (A).
A

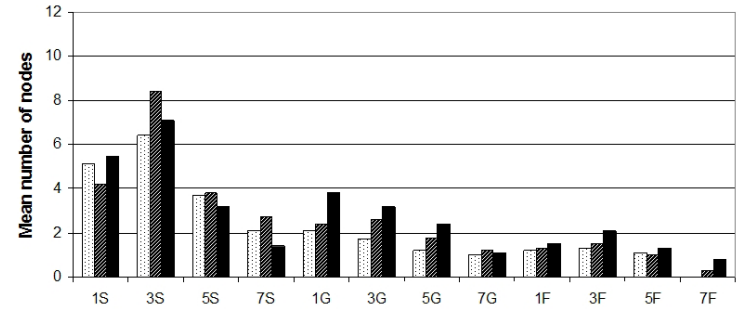

B

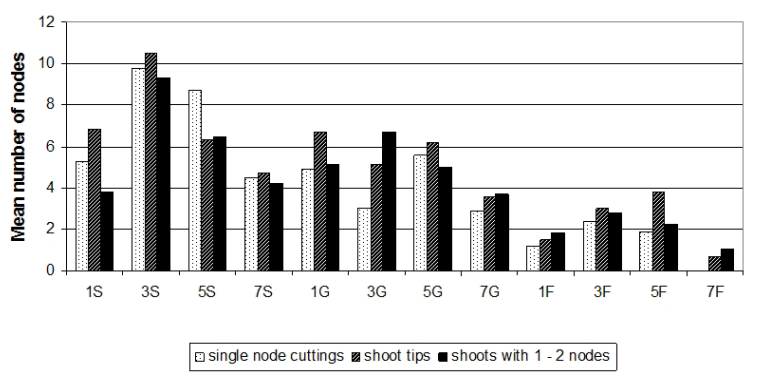

Fig. 3. The effect of graded concentration of different carbohydrate source on number of $D$. serotinus shoot nodes regenerated on full-strength MS basal medium (B) and half-strength MS basal medium (A)

(Figs. 2 and 3: the letters indicate different carbohydrate source and numbers indicate graded concentrations of different carbohydrate source; S-sucrose, G-glucose, F-fructose; 1 - 1\%, 3 - 3\%, 5 - 5\%, 7 - 7\%) 


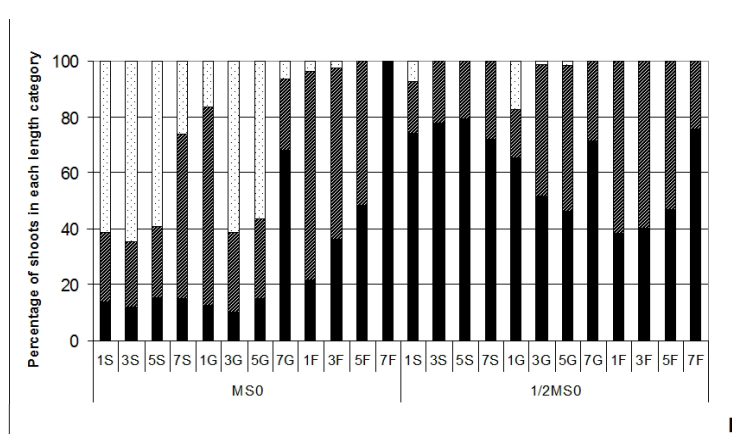

B

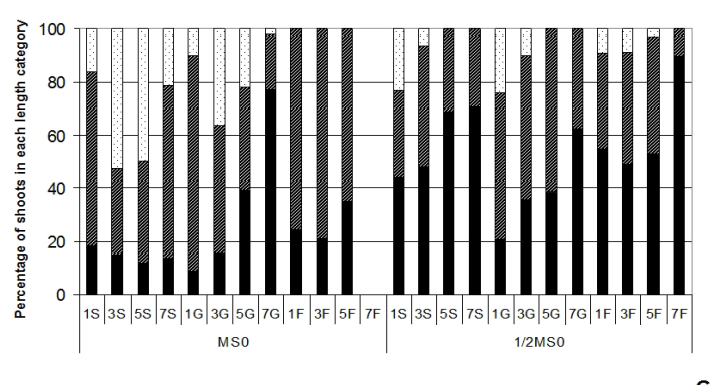

c

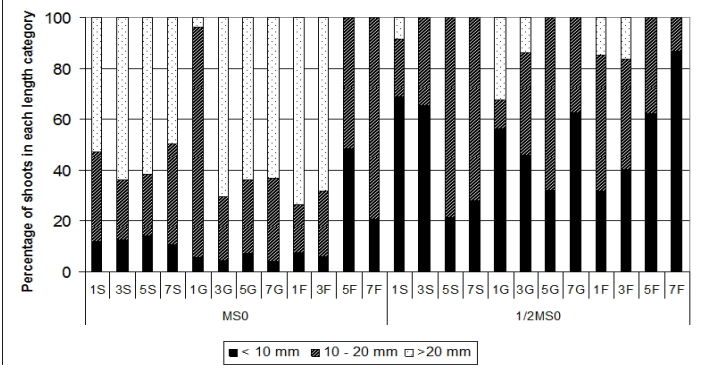

Fig. 4. The effect of graded concentration of different carbohydrate source on length of $D$. serotinus shoots regenerated on shoot tips (A), single node cuttings (B) and shoots (C)

(The letters indicate different carbohydrate source and numbers indicate graded concentrations of different carbohydrate source; S-sucrose, G-glucose, F-fructose; 1 - 1\%, 3 - 3\%, 5 - 5\%, 7 - 7\%; $\mathrm{MS}_{0}$-full-strength MS basal medium, $1 / 2 \mathrm{MS}_{0}$ - half-strength MS basal medium)

\section{Rooting and acclimatization}

The rooting of shoots was the most successful on halfstrength MS medium with $0.5 \mathrm{mg} \cdot \mathrm{L}^{-1} \mathrm{NAA}(76.7 \%)$, while the percentage of rooted shoots on MS medium with the same concentration of NAA was slightly lower (68.3\%), which corresponds to the results previously described by Marković et al. (2007). The concentration of MS salts (MS or half-strength MS) had no significant effect on the percentage of rooting when media with the same concentration of NAA were compared. Similarly, during the propagation of $D$. nardiformis the rooting on MS media with half-strength MS or even 1/4 MS did not significantly affect the quality of rooting (Holobiuc et al., 2010a).

Significantly poorer results were obtained on other media (Tab. 4), characterized by a lower concentration of NAA or a lack of hormones. The rooting percentage was lower than $50 \%$, and the average number of roots per ex- plant was almost halved (Tab. 4). The acclimatization of plantlets was the most successful (89\%) in a 4:1 mixture of peat and sand, the least successful acclimatization of plantlets was recorded in a mixture of peat, sand, garden soil and burned farmyard manure (80\%), and the acclimatized plants flowered the following year. When compared with other carnation species the rooting (68.3\%) and acclimatization (89\%) of D. serotinus obtained in this study can be considered satisfactory. Considerably better results in terms of rooting $(100 \%)$ and acclimatization (97\%) were obtained in the species D. deltoides L. (Markovic et al., 2013), and the rooting of D. superbus ssp. superbus was successful (100\%), although the acclimatization was relatively low (61.5\%) (Mikulík, 1999). However, in some studies of other carnation species the rooting percentage was significantly lower (D. henteri - 20\%, D. spiculifolius - 30\%, D. giganteus banaticus - 40\%) (Pop and Pamfil, 2011).

Tab. 4. Percentage of rooted shoots, average number of roots and the mean length of the longest root per explant

\begin{tabular}{ccccc}
\hline $\begin{array}{c}\text { NAA } \\
\left(\mathrm{mg} \cdot \mathrm{L}^{-1}\right)\end{array}$ & Medium & $\begin{array}{c}\text { Rooting } \\
\text { percentage } \\
(\%)\end{array}$ & $\begin{array}{c}\text { No. of roots } \\
\text { per explant }\end{array}$ & $\begin{array}{c}\text { Mean } \\
\text { length of } \\
\text { the longest } \\
\text { root (mm) }\end{array}$ \\
\hline 0 & $\mathrm{MS}_{0}$ & $28.3 \pm 6.1^{\mathrm{cd}}$ & $6.7 \pm 1.2^{\mathrm{bc}}$ & $16.8 \pm 2.6^{\mathrm{a}}$ \\
\hline 0.05 & $\mathrm{MS}_{0}$ & $23.3 \pm 6.5^{\mathrm{d}}$ & $7.2 \pm 1.0^{\mathrm{bc}}$ & $17.1 \pm 2.0^{\mathrm{a}}$ \\
0.1 & $\mathrm{MS}_{0}$ & $38.3 \pm 5.5^{\mathrm{c}}$ & $13.0 \pm 3.5^{\mathrm{b}}$ & $14.8 \pm 2.1^{\mathrm{a}}$ \\
\hline 0.5 & $\mathrm{MS}_{0}$ & $68.3 \pm 7.2^{\mathrm{ab}}$ & $21.1 \pm 3.1^{\mathrm{a}}$ & $14.5 \pm 1.7^{\mathrm{a}}$ \\
\hline 0 & $1 / 2 \mathrm{MS}_{0}$ & $35.0 \pm 7.1^{\mathrm{c}}$ & $5.6 \pm 1.3^{\mathrm{c}}$ & $15.5 \pm 2.7^{\mathrm{a}}$ \\
\hline 0.05 & $1 / 2 \mathrm{MS}_{0}$ & $36.7 \pm 6.8^{\mathrm{c}}$ & $5.8 \pm 1.8^{\mathrm{c}}$ & $16.2 \pm 2.3^{\mathrm{a}}$ \\
\hline 0.1 & $1 / 2 \mathrm{MS}_{0}$ & $48.4 \pm 4.9^{\mathrm{bc}}$ & $6.3 \pm 1.2^{\mathrm{bc}}$ & $11.3 \pm 1.8^{\mathrm{ab}}$ \\
\hline 0.5 & $1 / 2 \mathrm{MS}_{0}$ & $76.7 \pm 7.2^{\mathrm{a}}$ & $10.5 \pm 1.8^{\mathrm{b}}$ & $12.8 \pm 1.5^{\mathrm{ab}}$ \\
\hline
\end{tabular}

$\mathrm{MS}_{0}$ - basal medium containing MS mineral salts; $1 / 2 \mathrm{MS}_{0}$ - basal medium containing half strength MS mineral salts;

Note: Values followed by different letters are significantly different at the $\mathrm{P}<0.05$ level according to the least significant difference test

\section{Conclusion}

Taking the obtained results into account, it can be concluded that micropropagation of the endangered species D. serotinus should be performed on half-strength MS medium with a $\mathrm{pH}$ level ranging from 5.8 to 6.8 . The most favourable sugar as carbon source is sucrose supplied at a concentration of 3\%, and shoots with 1-2 nodes should be used as explants, although satisfactory results have also been achieved by using shoot tips. This research provide complete protocol for successful in vitro propagation of the critically endangered species D. serotinus, and its results could be useful for both activities aimed at biodiversity protection in sandy regions of Pannonian Basin and floricultural production of this species. 
376

\section{Acknowledgement}

This work was supported by the Ministry of Education and Science of Serbia, grant No 43007.

\section{References}

Barghchi M (1988). Micropropagation of Alnus cordata (Loisel.) Loisel. Plant Cell Tiss Org 15:233-244.

Bhatia P, Ashwath N (2005). Effect of Medium pH on Shoot Regeneration from Cotyledonary Explants of Tomato. Biotechnology 4(1):7-10.

Boža P (1999). Dianthus serotinus Waldst. \& Kit., p. 252-254. In: Stevanović V (ed.). Crvena knjiga flore Srbije. Ministarstvo za životnu sredinu Republike Srbije, Biološki fakultet Univerziteta u Beogradu, Zavod za zaštitu prirode Republike Srbije, Beograd.

Butiuc-Keul A, Suteu A, Munteanu-Deliu C, Deliu C (2001). Study on the in vitro preservation of Dianthus spiculifolius Schur. Contrib Bot 36:137-145.

Chauvin JE, Salesses G (1988). Advances in chestnut micropropagation (Castanea sp.). Acta Hort 227:340-345.

Cristea V (2010). Photoautotrophic in vitro culture of endemic and endangered Dianthus species from Romania. Todesco, Cluj-Napoca, 227 p. (in Romanian).

Cristea V, Brummer AT, Jarda L, Miclăuş M (2010). In vitro culture initiation and phytohormonal influence on Dianthus benteri - a Romanian endemic species. Rom Biotech Lett $15(1): 25-33$.

Cuenca B, Vieitez AM (2000). Influence of carbon source on shoot multiplication and adventitious bud regeneration in in vitro beech cultures. Plant Growth Regul 32:1-12.

Debnath SC (2005). Effects of carbon source and concentration on development of lingonberry (Vaccinium vitis-idaea L.) shoots cultivated in in vitro from nodal explants. In Vitro Cell Dev Pl 41:145-150.

Ebrahim MKH, Ibrahim IA (2000). Influence of medium solidification and $\mathrm{pH}$ value on in vitro propagation of $\mathrm{Ma}$ ranta leuconeura cv. Kerchoviana. Sci Hortic - Amsterdam 86:211-221.

Gajić M (1986). Flora i vegetacija Subotičko-horgoške peščare, Šumarski fakultet Univerzitet u Beogradu, Beograd, Šumsko gazdinstvo, Subotica 163-164 p. (in Serbian).

George EF, de Klerk GJ (2008). The Components of Plant Tissue Culture Media I: Macro- and Micro-Nutrients, p. 65114. In: George EF, Hall M A, De Klerk DJ (Eds.). Plant Propagation by Tissue Culture, $3^{\text {rd }}$ Edition, Springer, AA Dordrecht, Netherlands.

Harbage JF, Stimart DP (1996). Effect of $\mathrm{pH}$ and 1-indole-3butyric acid (IBA) on ro oting of apple microcuttings. J Am Soc Hort Sci 121:1049-1053.

Holobiuc I, Blindu R (2006). Improvement of the micropropagation and in vitro medium-term preservation of some rare Dianthus species. Contrib Bot 41:143-151.
Holobiuc I, Blindu R, Cristea V (2009). Researches Concerning In Vitro Conservation of the Rare Plant Species Dianthus nardiformis Janka. Biotechnol Biotech Eq 23:221-224.

Holobiuc I, Catana R, Cristea V (2010a). Researches concerning in vitro cultures optimization of the vulnerable species Dianthus nardiformis Janka. Analele Universitatii din Oradea - Fascicula Biologie 17(1):116-121.

Holobiuc I, Mitoi M, Blindu R, Helepciuc F (2010b). The establishment of an in vitro gene bank in Dianthus spiculifolius Schur. and D. glacialis ssp. gelidus (Schott Nym. et Kotschy) Tutin: II. Medium-term cultures characterization in minimal growth conditions. Rom Biotech Lett 15(2):5111-5119.

Jethwani V, Kothari SL (1993). Micropropagation of Dianthus barbatus and $D$. chinensis through cotyledonary node culture. Plant Tiss Cult 2:91-96.

Jethwani V, Sharma VK, Kothari SL (1994). Micropropagation of Dianthus chinensis and Dianthus barbatus through shoot tip culture. J Indian Bot Soc 73:357-358.

Kovác J (1995). Micropropagation of Dianthus arenarius subsp. bohemicus - an endangered endemic from the Czech Republic. Botanic Gardens Micropropagation News 8:106-108.

Law on Environmental Protection, Rulebook on protected species (2010). Official Gazette of the Republic of Serbia, No. 5/10, Belgrade, Serbia.

Leifert C, Pryce S, Lumsden PJ, Waites WM (1992). Effect of medium acidity on growth and rooting of different plant species growing in vitro. Plant Cell Tiss Org 30(3):171179.

Marković M, Grbić M, Skočajić D, Đunisijević-Bojović D (2007). Uticaj balansa fitohormona na multiplikaciju izdanaka i ožiljavanje vrste Dianthus serotinus Waldst. \& Kit. Glasnik Šumarskog Fakulteta 95:83-94.

Marković M, Popović M, Vilotić D (2013). Micropropagation of Dianthus deltoides L. through shoot tip and nodal cuttings culture. Arch Biol Sci 65(1):17-22.

Miclăuş M, Cristea V, Deliu C (2003). Micropropagation on Dianthus petraeus W. et K. ssp. simonkaianus (Péterfi) Tutin. Contrib Bot 38:77-84.

Mikulík J (1999). Propagation of endangered plant species by tissue cultures. Acta Universitatis Palackianae Olomucensis, Biologica 37:27-33.

Mišić D, Ghalawenji N, Grubišić D, Konjević R (2005a). Micropropagation and Reintroduction of Nepeta rtanjensis, an Endemic and Critically Endangered Perennial of Serbia. Phyton 45:9-20.

Mišić D, Maksimović V, Todorović S, Grubisić D, Konjević R (2005b). Influence of carbohydrate source on Nepeta rtanjensis growth, morphogenesis and nepetalactone production in vitro. Israel J Plant Sci 53:103-108.

Mohamed MAH, Alsadon AA (2010). Influence of ventilation and sucrose on growth and leaf anatomy of micropropagated potato plantlets. Sci Hortic 123:295-300.

Murashige T, Skoog F (1962). A revised medium for rapid 
growth and bioassays with tobacco tissue cultures. Physiol Plantarum 15:473-497.

Nowak B, Miczynski K, Hudy L (2004). Sugar uptake and utilization during adventitious bud differentiation on in vitro leaf explants of 'Wegierka Zwykta' plum (Prunus domestica). Plant Cell Tiss Org 76:255-260.

Ostrolucka MG, Gajdosova A, Ondruskova E, Lateekova A, Libiakova G (2010). Effect of medium pH on Axillary Shoot Proliferation of Selected Vaccinium vitis-idaea L. Cultivars. Acta Biol Cracov Bot 52(2):92-96.

Ostrolucka MG, Libiakova G, Ondruskova E, Gajdosova A (2004). In vitro propagation of Vaccinium species. Acta Universitatis Latviensis, Biology 676:207-212.

Papafotiou M, Stragas J (2009). Seed germination and in vitro propagation of Dianthus fruticosus L. ISHS Acta Hort 813:481-484.

Pareek A, Kantia A, Kothari SL (2004). In vitro cloning of ornamental species of Dianthus. Indian J Biotech 3:263-266.

Pence VC (1999). The application of biotechnology for the conservation of endangered plants, p. 227-241. In: Benson EE (Ed.). Plant Conservation Biotechnology, Chapter 15, Taylor and Francis, London.

Perić M, Dmitrović S, Živković S, Filipović B, Skorić M, Simonović A, Todorović S (2012). In Vitro Growth, Morphogenesis, and Acclimatization of Endangered Rindera umbellata (Waldst. \& Kit.) Bunge. Hort Science 47:11231128.

Pop T, Pamfil D (2011). In vitro Preservation of Three Species of Dianthus from Romania. Bulletin UASVM Hort 68(1):414-422.

Radojević LJ, Ćalić-Dragosavac D, Špirić J, Stevanović B, Stevanović V (2010). In vitro umnožavanje u kulturi segmenata stabla of Dianthus ciliatus ssp. dalmaticus i $D$. giganteus ssp. croaticus (Caryophyllaceae). Botanica Serbica 34(2):153-161
Radojević LJ, Marinković N, Jevremović S (1997). Vegetativno razmnožavanje u kulturi meristema i segmenata stabla $D i$ anthus petraeus Waldst. et Kit. subsp. noeanus. Glasnik instituta za botaniku i Botaničke bašte Univerziteta u Beogradu 31:73-77.

Radojević LJ, Špirić J, Stevanović B, Stevanović V (2006). In vitro culture of several endemic species Dianthus in Balkan Peninsula. Proceedings of XXII International Symposium Section Ornamentals, 11-15 September 2006, 36. Sanremo, Italy.

Steffen JD, Sachs RM, Hackett WP (1988). Growth and development of reproductive and vegetative tissues of Bougainvillea cultured in vitro as a function of carbohydrate. Am J Bot 75:1219-1224.

Thorpe T, Stasolla C, Yeung EC, de Klerk GJ, Roberts A, George EF (2008). The Components of Plant Tissue Culture Media II: Organic Additions, Osmotic and pH Effects, and Support Systems, p. 115-174. In: George EF, Hall MA, De Klerk DJ (Eds.). Plant Propagation by Tissue Culture, $3^{\text {rd }}$ Edition, Springer, Dordrecht, Netherlands.

Todorović S, Grubisić D, Giba Z, Mišić D, Konjević R (2006). Sucrose effects on in vitro fruiting and seed production of Centaurium pulchellum. Biol Plantarum 50:771-774.

Tremblay FM, Lalonde M (1984). Requirements for in vitro propagation of seven nitrogen-fixing Alnus species. Plant Cell Tiss Org 3:189-199.

Yu X, Reed BM (1993). Improved shoot multiplication of mature hazelnut (Corylus avelana L.) in vitro using glucose as carbon source. Plant Cell Rep 12:256-259. 